\title{
Physical and biological factors influencing mussel (Mytilus trossulus, M. edulis) settlement on a wave-exposed rocky shore
}

\author{
Heather L. Hunt*, Robert E. Scheibling \\ Department of Biology, Dalhousie University, Halifax, Nova Scotia, Canada B3H 4J1
}

\begin{abstract}
Settlement rates of mussels Mytilus trossulus and $M$. edulis on artificial collectors (aquarium filter wool) and natural substrata were measured in tidepools and on emergent rock in recently ice-scoured and non-scoured regions of a rocky shore near Halifax, Nova Scotia, Canada. Patterns of abundance and size distribution of mussel settlers differed markedly between artificial collectors and natural substrata. Settlement rate on artificial collectors was directly related to water flux, and was highest on ice-scoured emergent rock and lowest in non-scoured tidepools. Settlement rate on natural substrata was related to a suite of biological (macroalgal/barnacle cover) and physical factors (water flux, tidal height, flushing time), and was highest in ice-scoured tidepools and lowest on ice-scoured emergent rock. Large postlarval mussels ( $>5 \mathrm{~mm}$ shell length) were common on natural substrata but rare on artificial collectors. Recruitment patterns of mussels on natural substrata reflected the distribution of settlers, suggesting that settlement patterns are important in determining the distribution and abundance of mussels in this population.
\end{abstract}

KEY WORDS: lce-scour - Intertidal zone Larval supply $\cdot$ Mussels $\cdot$ Mytilus $\cdot$ Recruitment Settlement . Tidepools

\section{INTRODUCTION}

Spatial variation in settlement of larvae of benthic marine invertebrates arises through a combination of passive (hydrodynamic) and active (behavioural) processes operating at various scales (reviewed by Butman 1987). Larvae tend to be passively deposited at large spatial scales (tens of metres to tens of kilometres) since horizontal advection usually exceeds larval swimming speeds, although some larvae can vertically migrate between water masses. Active habitat selection becomes important at smaller scales (centimetres to metres) as larvae respond to various abiotic (e.g. surface texture and chemistry) and biotic (e.g. microbial films, conspecifics, and other macrobenthic species) cues associated with the substratum (reviewed by Pawlik 1992). However, hydrodynamic processes, such as turbulent eddies around biotic

\footnotetext{
•E-mail: hlhunt@is2.dal.ca
}

roughness elements, may also influence the smallscale distribution of settlers (e.g. Eckman 1983, 1987, Havenhand \& Svane 1991, Harvey et al, 1995). Settlement patterns may be reflected in recruitment patterns, depending on the intensity and spatial variation of early post-settlement mortality (Keough \& Downes 1982).

In their natural habitat, recently settled mussels (Mytilus spp.) are usually associated with filamentous substrata (primarily macroalgae) or small crevices and depressions in the bottom (reviewed by Seed 1976, Seed \& Suchanek 1992). Laboratory studies have shown that larvae of $M$. edulis and postlarvae of $M$. galloprovincialis settle almost exclusively on filamentous substrata (Bayne 1965, Petersen 1984, Eyster \& Pechenik 1987, Cáceres-Martínez et al. 1994). A variety of artificial substrata (including rubberized hair pads, plastic panels, ropes, jute pads, shag rugs, and plastic pot scrubbers) have been used to collect mussel settlers (Menge 1978, King et al. 1990 and references therein, Petraitis 1991, Cáceres-Martínez et al. 1994, 
Menge et al. 1994, Molares \& Fuentes 1995), since they provide a standardized surface which is easy to sample. The abundance of mussel settlers on artificial substrata probably reflects larval supply, as observed for freshwater zebra mussels (Martel et al. 1994) and estuarine Dungeness crabs (Eggleston \& Armstrong 1995). King et al. (1990) observed that the temporal pattern of mussel settlement on an artificial substratum (nylon pot scrubbers) was similar to that recorded on filamentous algae and adult mussels at the same site.

Along the Atlantic coast of Nova Scotia, Canada, 2 species of mussels (Mytilus trossulus and Mytilus edulis, hereafter Mytilus) co-occur in the low and mid intertidal zones, but they cannot be distinguished visually at small sizes (Pedersen 1991, Mallet \& Carver 1995). Mussels in tidepools generally occur in centimetre-scale patches (Hunt \& Scheibling 1995), whereas mussels on emergent rock tend to form more extensive beds (authors' pers. obs.). This pattern may reflect greater settlement and/or lower post-settlement mortality on emergent rock. Tidepools and emergent rock differ in several aspects which may influence mussel settlement rate: (1) they have different macroalgal assemblages (reviewed by Metaxas \& Scheibling 1993) which are the substrata for settlement; (2) they are differentially affected by ice-scour which occurs sporadically along the Atlantic coast of Nova Scotia (McCook \& Chapman 1991, Minchinton et al. in press) and generally disturbs the biota of tidepools less than that of emergent rock; and (3) settlement may continue during the period of tidal isolation in tidepools but not on emergent rock

In this study, we examine patterns of settlement of Mytilus in tidepools and on emergent rock, both in icescoured and non-scoured regions of an exposed shore. Comparisons of settlement rates on artificial collectors and natural substrata enable us to examine the relative roles of larval supply (as reflected by settlement on collectors) and substratum type in shaping settlement patterns of mussels. We relate the observed patterns of settlement to physical and biological characteristics of the local environment, and examine the relationship between settlement and recruitment of mussels on this shore.

\section{MATERIALS AND METHODS}

Physical environment. This study was conducted in September and October 1994 on a rocky shore at Cranberry Cove $\left(44^{\circ} 28^{\prime} \mathrm{N}, 63^{\circ} 56^{\prime} \mathrm{W}\right.$ ) near Halifax, Nova Scotia, Canada The shore is composed of granite platforms and outcrops, and exposed to southerly swells of up to $10 \mathrm{~m}$ (significant wave height) in fall and winter For further description of the site see Metaxas et al. (1994) and Hunt \& Scheibling (1995).
We examined settlement and recruitment of mussels in 2 habitats (tidepools and emergent rock) within each of 2 strata (areas scoured by ice during winter 1992-93 and non-scoured areas). Emergent rock surfaces were scoured bare except for the scattered thalli of crustose macroalgae, whereas some upright macroalgae remained in scoured tidepools. By September 1994, foliose macroalgae had become re-established in icescoured areas, and mussels were abundant in all areas except ice-scoured emergent rock. We selected 12 sampling locations along a horizontal distance of $\sim 1 \mathrm{~km}$ of shoreline to make up 3 replicates of each of the 4 combinations of habitat and stratum. Tidepool locations ranged from 2.7 to $7.2 \mathrm{~m}$ in length, 1.1 to $2.8 \mathrm{~m}$ in width, and 0.3 to $0.6 \mathrm{~m}$ in depth; locations on emergent rock were similar in area. We measured the height of each location above a chart datum using a transit level in May 1995. We measured flushing time for each of the 6 tidepools in August 1993 and June 1994 as the time taken for a fluorescent red dye (Rhodamine B, Sigma Chemicals), added at low tide at an initial concentration of 1.4 to $6.4 \mathrm{mg} \mathrm{l}^{-1}$, to become undetectable in a spectrophotometer (Perkin-Elmer, Lambda 3B, Oak Brook, IL, USA). We measured isolation time of tidepoois (the period during which there is no sea water input) on the same dates as flushing time.

We measured relative water flux at each location as the dissolution rate of dental stone (calcium sulfate) (Yund et al. 1991). The dental stone (Denstone ${ }^{1}$ Golden, Miles Dental Products, South Bend, IN, USA) was cast in cylindrical molds $2 \mathrm{~cm}$ high and $11 \mathrm{~cm}$ in diameter. After drying at room temperature for at least $24 \mathrm{~h}$ and then at $40^{\circ} \mathrm{C}$ for an additional $24 \mathrm{~h}$, the sides and bottom of the cylinders were coated with polyurethane so that only the top surface was exposed to flow. The cylinders were then dried for a further $24 \mathrm{~h}$ at room. temperature. The cylinders were fastened to $11 \times 15 \mathrm{~cm}$ rectangles of galvanized mesh $(0.6 \mathrm{~cm}$ mesh size) with epoxy putty (Z-Spar A-788 Splash Zone Compound ${ }^{*}$, Kop-Coat Inc., Los Angeles, CA, USA), dried at $40^{\circ} \mathrm{C}$ for $24 \mathrm{~h}$, and then weighed. We measured relative water flux for two 5 to $6 \mathrm{~d}$ periods (May 15 to 20 and June 30 to July 6, 1995). During each period, 2 cylinders were bolted to the substratum at each location; another 2 cylinders were deployed above the tidal range as controls for losses not due to water flow, such as transport and rain. After each period, the cylinders were returned to the laboratory, rinsed in fresh water, dried at room temperature for $48 \mathrm{~h}$ and then at $40^{\circ} \mathrm{C}$ for an additional $24 \mathrm{~h}$, and then weighed. In July, dissolution rate was not measured for 1 location because both cylinders were abraded by macroalgae. However, the missing value was estimated from a regression. equation relating dissolution rates in July $(J)$ to those in May $(M)$ at all other locations: $J=0.933 M-12.719$ 
$\left(\mathrm{r}^{2}=0.802 ; F_{1.9}=36.344 ; \mathrm{p}<0.001\right)$. The ranks of dissolution rates in May and July were strongly correlated (Spearman Rank Correlation: $r_{\mathrm{s}}=0.944 ; \mathrm{p}<0.001$ ); these ranks were averaged to give an index of water flux for multiple regression and principal components analysis (see 'Statistical analysis').

Significant wave heights (SWH: average height of the largest third of all waves measured) were recorded at a station $\left(44^{\circ} 50^{\prime} \mathrm{N}, 63^{\circ} 25^{\prime} \mathrm{W}\right) \sim 40 \mathrm{~km}$ from the study site (data provided by Department of Fisheries and Oceans, Canada).

Larval/postlarval abundance. We measured the availability of Mytilus larvae and postlarvae in sea water at high tide on September 24 and October 8 , 1994, the same dates that artificial collectors were deployed (see 'Settlement and recruitment'). Three 301 samples of sea water were collected at each of 3 (September) or 4 (October) positions separated by 100 to $400 \mathrm{~m}$ along $\sim 1 \mathrm{~km}$ of shoreline. We hand-pumped the water with a bilge pump through a hose fastened to the substratum at the same height on the shore as our artificial collectors. The water sample was filtered through a $60 \mu \mathrm{m}$ filter, which was rinsed with filtered sea water and preserved in $70 \%$ ethanol. Larvae and postlarvae were enumerated and measured in the laboratory under a dissecting microscope.

Settlement and recruitment. For benthic marine invertebrates with dispersing larvae, settlement includes attachment to the substratum and metamorphosis, while recruitment refers to survival until the organism is counted by an observer (Keough \& Downes 1982). Defining settlement and recruitment in terms of sampling period is more problematic for Mytilus, which remains mobile for some time after settlement (reviewed by Seed \& Suchanek 1992), than for truly sessile species. In this study, we define settlers as mussels collected after a period of hours to days, and recruits as those collected after a period of $5 \mathrm{mo}$. In this region, settlement of Mytilus is protracted, occurring over a 9 mo period, with an annual peak in late summer or early fall (Pedersen 1991, authors' unpubl. data).

Genetic analysis was used to identify the species of mussels present at the study site. A sample of 27 older juvenile and adult mussels [ 4 to $44 \mathrm{~mm}$ shell length (SL)] was collected in March 1996 and analysed by polymerase chain reaction/restriction fragment length polymorphism assays using a marker for the female mitochondrial DNA lineage (Rawson \& Hilbish 1995a, b) and a nuclear DNA marker for the adhesive foot protein (Rawson et al. in press). The analysis revealed that $\sim 80 \%$ of mussels in both tidepools and emergent rock were Mytilus trossulus. At another wave-exposed shore in Nova Scotia (ca $30 \mathrm{~km}$ away), Pedersen (1991) found that 77 to $91 \%$ of settlers
(<1 $\mathrm{mm} \mathrm{SL}$ ) and 76 to $90 \%$ of older individuals (from 6 , 10, and 24 mo old mussel patches) were M. trossulus. Therefore, it is likely that most of the settlers that we sampled were $M$ trossulus.

We deployed artificial collectors to sample Mytilus settlers on September 24 and October 8, 1994. The collectors [similar to those used by Pearce \& Bourget (1996) for scallop spat] were made of $9 \times 11 \mathrm{~cm}$ pouches of plastic Vexar mesh ( $3 \mathrm{~mm}$ mesh size), filled with -1.5 $\mathrm{g}$ of polyester wool for aquarium filters ('Poly' Filter Wool ${ }^{\otimes}$, Rolf C. Hagen Inc., Montreal, Quebec, Canada). The collectors were placed in running sea water in the laboratory for $-1 \mathrm{wk}$ before use to allow colonization by microflora. At each location, 4 collectors were bolted to the substratum (through a grommet in the center of the pouch) before tidal immersion, and removed after 6.5 to $10 \mathrm{~h}$ when the tide receded. A second set of collectors was placed in the tidepools at this time, and removed after 2.5 to $5.5 \mathrm{~h}$, before immersion by the incoming tide. The collectors were returned to the laboratory and frozen until they were processed. Mussels from each collector were counted and SL was measured using an ocular micrometer (accuracy: $\pm 30 \mu \mathrm{m}$ ). Mussels on both filter wool and Vexar mesh were counted, but those on the mesh were rare.

At each location, we also sampled settlement of Mytilus in three $10 \times 10 \mathrm{~cm}$ quadrats on the natural substratum. We prepared these quadrats by removing the existing mussels with forceps or a pipette to avoid disturbing the rest of the macrobenthic community. We also removed mussels (with a paint scraper) from a $10 \mathrm{~cm}$ border around each quadrat to limit migration into the quadrat. The quadrats were spaced at least $10 \mathrm{~cm}$ apart at each location and marked by stainless steel screws in plastic anchors. We collected recently settled mussels from each quadrat after two 5 d intervals (September 22 to 26 and October 7 to 11, 1994). Three other quadrats at each location were similarly prepared on May 20 and 21, 1994 and sampled after -5 mo (October 17 to 29 ) to estimate mussel recruitment. The mussel samples were returned to the laboratory and frozen until they were processed as described above.

In October 1994, we estimated the cover of macroalgae and barnacles (Semibalanus balanoides, the only sessile macrofaunal species besides Mytilus) in each of the settlement quadrats. A plexiglass panel with 20 random points was placed over a quadrat and the number of points overlying each species/group were counted and expressed as a percentage of the total. Macroalgae were assigned to functional form groups after Littler (1980) and Littler \& Littler (1984): filamentous, coarsely branched, thick leathery, jointed calcareous, and crustose forms. 
Statistical analysis. We used 3-way analysis of variance (ANOVA) to analyze the settlement/recruitment rate of Mytilus on artificial collectors and natural substrata. Habitat (tidepool and emergent rock) and Stratum (scoured and non-scoured) were fixed factors, each with 2 levels, and Location was a random factor nested within Habitat $\times$ Stratum, with 3 levels. If Location was non-significant at $\alpha=0.250$, we removed this term from the analysis and calculated a pooled estimate of the residual error (Winer 1971). If Location was significant at $\alpha=0.05$, we examined the Location effect within each combination of Habitat $\times$ Stratum. We used Student-Newman-Keuls (SNK) tests $(\alpha=0.05$ ) for post hoc comparisons of means. If necessary, counts of mussels $(x)$ were $\ln (x+1)$ transformed to homogenize variances (Cochran's C-test: $\alpha=0.05$ ).

We used Kolmogorov-Smirnov tests (Seigel \& Castellan 1988) to compare size distributions of mussels among habitats and strata for samples from both artificial collectors and natural substrata.

We used forwards stepwise multiple regression to examine the relationship between settlement rate of Mytilus settlers on artificial collectors and the physical characteristics of the locations (water flux index, tidal height, and flushing time). We did regressions for tidepools and emergent rock separately, as well as for the 2 habitats combined. For analysis of settlement on natural substrata, we used principal components analysis (PCA), based on both the physical and the biological (cover of macroalgal groups/barnacles) characteristics of the locations, to reduce the number of variables needed to explain the total variance in the data (Kleinbaum et al. 1988). Only PCA factors with eigenvalues $>1$ were used in stepwise regression. Also, we analyzed 2 size classes of mussels $1<2$ and $>2 \mathrm{~mm} \mathrm{SL}$ ) separately because the larger settlers (postlarvae $>2 \mathrm{~mm}$ ) may have different substratum preferences than smaller ones (Seed 1969). Counts of mussel settlers on natural substrata were $\ln (x+1)$ or square transformed, if necessary, to homogenize variances (as detected in plots of residuals).

\section{RESULTS}

\section{Environmental variability}

The height of the sampling locations ranged from 0.80 to $2.33 \mathrm{~m}$ above the chart datum (Fig 1a), and did not differ significantly between tidepool and emergent rock habitats $\left(F_{1.8}=1.01 ; \mathrm{p}=0.344\right)$ or between icescoured and non-scoured strata $\left(F_{1,8}=3.04 ; \mathrm{p}=0.119\right)$, and there was no significant interaction between Habitat and Stratum $\left(F_{1.8}=1.22 ; p=0.301\right)$. Ice-scoured tidepools were flushed within 2.8 to 3 h after low tide,
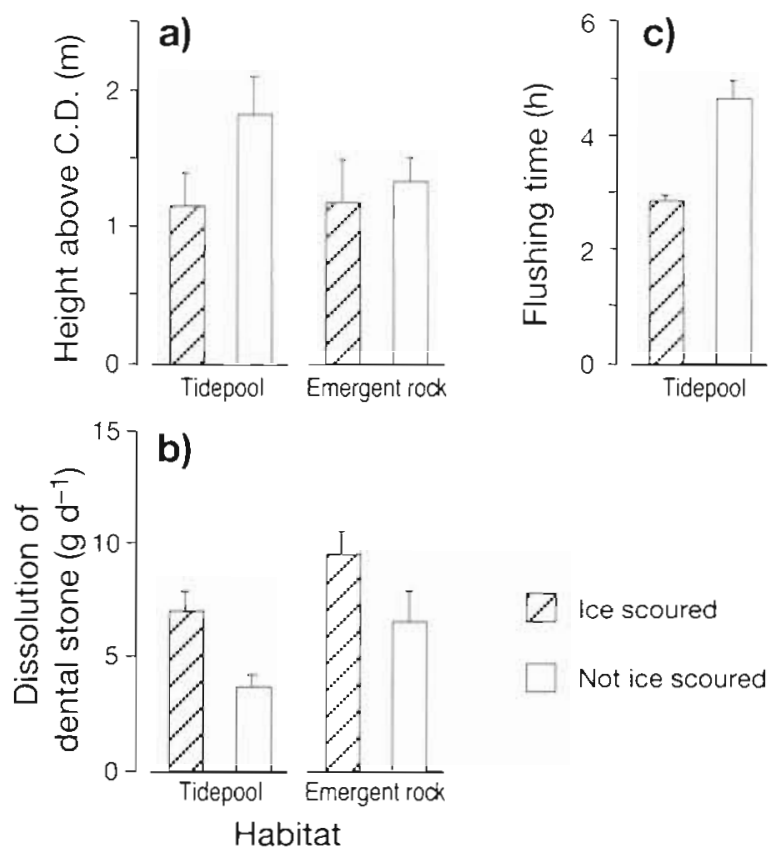

Fig. 1. Physical characteristics of the sampling locations at Cramberry Cove, Nova Scotia, Canada. Mean \pm SE ( $n=3$ locations per Habitat $\times$ Stratum combination): (a) height of locations above chart datum ( $\mathrm{m})$; (b) water flux index: dissolution of dental stone $\left(\mathrm{g} \mathrm{d}^{-1}\right)$ (average of 2 sampling periods); (c) flushing time: number of hours required after low tide for the pool to be flushed with new sea water (average of 2 sampling dates)

significantly faster $\left(t_{4}=5.329 ; \mathrm{p}=0.006\right)$ than nonscoured tidepools which were flushed in 4.0 to $5.0 \mathrm{~h}$ (Fig. 1c). Average isolation times during low tide were 3.8 to $4.8 \mathrm{~h}$ for scoured tidepools and emergent rock and 6.5 to $8 \mathrm{~h}$ for non-scoured tidepools.

The water flux index, measured as the dissolution rate of dental stone, differed significantly with Habitat $\left(F_{1,16}=37.55 ; \mathrm{p}=0.0001\right)$, Stratum $\left(F_{1,16}=48.14\right.$; $\mathrm{p}=0.0001)$, and Sampling Date $\left(F_{1.16}=91.79 ; \mathrm{p}=\right.$ 0.0001 ), but there were no significant interactions between these factors $(p>0.40)$. Water flux was higher on emergent rock than in tidepools and in ice-scoured than non-scoured areas (Fig. 1b). Although water flux and mussel settlement were measured at different times of the year, SWH were similar during both measurement periods: mean $\mathrm{SWH}( \pm \mathrm{SD})$ were $1.62 \pm 0.54$ and $0.73 \pm 0.18 \mathrm{~m}$ during water flux measurements in May and June 1995, respectively, and $0.97 \pm 0.23$ and $0.86 \pm 0.17 \mathrm{~m}$ during sampling of mussel settlement in September and October 1994, respectively.

The macrobenthic assemblage varied markedly between habitats and strata (Fig. 2). Filamentous and jointed calcareous macroalgrae were found only in tidepools. Conversely, thick leathery macroalgae were 


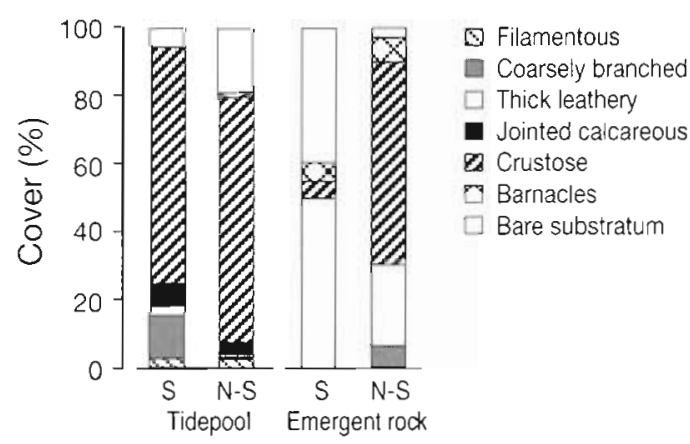

Fig. 2. Mean percentage cover of 5 functional form groups of macroalgae and of bare substratum and barnacles in icescoured (S) and non-scoured (N-S) tidepools and emergent rock in October 1994

rare $(<3 \%$ cover) in tidepools, but common on emergent rock (24 and 50\% for scoured and non-scoured strata, respectively). Ice-scoured emergent rock lacked coarsely branched macroalgae and had a much lower cover $(5 \%)$ of crustose macroalgae than other Habitat $x$ Stratum combinations ( 59 to $72 \%$ ). Barnacle cover was somewhat higher on emergent rock $(6$ and $7 \%$ for scoured and non-scoured strata, respectively) than in tidepools $(<1 \%)$

\section{Larval/postlarval availability}

The abundance of Mytilus larvae and postlarvae $>250 \mu \mathrm{m}$ (the size at competency, Bayne 1965) in the sea at high tide (Fig. 3) did not vary significantly along $\sim 1 \mathrm{~km}$ of shoreline within our study site, in either September $\left(F_{2,6}=1.750 ; \mathrm{p}=0.252\right)$ or October $\left(F_{3,8}=\right.$ 2.465; $\mathrm{p}=0.137$ ). However, the mean proportion of mussels $>250 \mu \mathrm{m}$ in these samples increased from $16 \%$ $(\mathrm{n}=37)$ to $92 \%(\mathrm{n}=91)$ between the 2 sampling periods (Fig. 3).

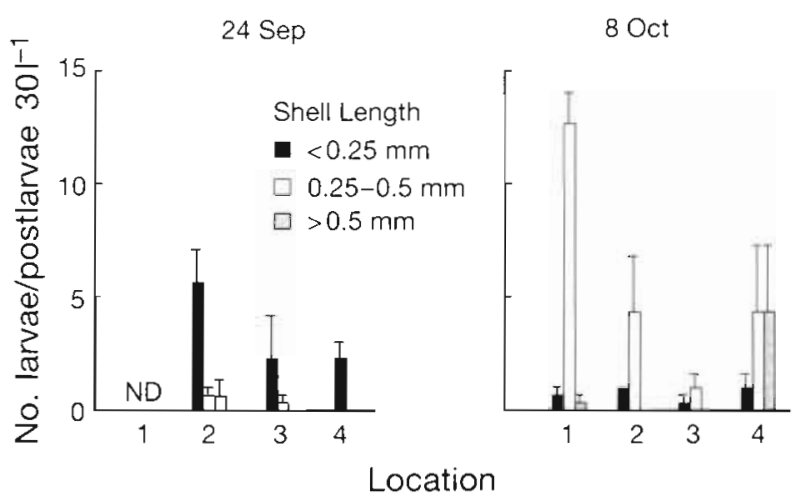

Fig. 3. Mean $( \pm \mathrm{SE})$ concentration of Mytilus larvae and postlarvae [no. $\left.(301)^{-1}\right]$ in sea water at high tide at 4 positions along $\sim 1 \mathrm{~km}$ of shoreline on September 24 and October 8 , 1994. $\mathrm{n}=3$ samples at each location. $\mathrm{ND}=$ no data

\section{Settlement on artificial collectors}

In September 1994, settlement rate of Mytilus on the artificial collectors did not vary significantly with Location (within Habitat $\times$ Stratum), Stratum or Habitat (Table 1 \& Fig. 4a). In October 1994, settlement rate also did not vary significantly with Location, but it was significantly higher in the ice-scoured than nonscoured stratum and significantly higher on emergent rock than in tidepools; there was no significant interaction between Stratum and Habitat (Table 1 \& Fig. 4a). In September, 33 and $38 \%$ of mussels in scoured and non-scoured tidepools, respectively, settled during the

Table 1 Three-way ANOVA of abundance of Mytilus settlers on artificial collectors (no. collector ${ }^{-1}$ tidal cycle ${ }^{-1}$ ) and natural substrata [no. $(100 \mathrm{~cm})^{-2}(5 \mathrm{~d})^{-1}$ ] in September and October 1994, and of Mytilus recruits on natural substrata [no. $\left.(100 \mathrm{~cm})^{-2}\right]$ between May and October 1994. Factors are Habitat $(\mathrm{H})$, Stratum (S), and Location (L) (nested within $\mathrm{H} \times \mathrm{S}$ ). For artificial collectors, degrees of freedom are: $\mathrm{L}(\mathrm{H} \times \mathrm{S})=8,36$ $\mathrm{H}, \mathrm{S}$ and $\mathrm{H} \times \mathrm{S}=1,8$ if $\mathrm{p}_{\mathrm{LHXS} \mid}<0.25$ and $\mathrm{df}=1,44$ if $\mathrm{p}_{\mathrm{L}(\mathrm{H} \times \mathrm{S} \mid}>$ 0.25 . For natural substrata, degrees of freedom are: $\mathrm{L}(\mathrm{H} \times \mathrm{S})=$ 8, 24; $\mathrm{H}, \mathrm{S}$ and $\mathrm{H} \times \mathrm{S}=1,8$ if $\mathrm{p}_{\llcorner(\mathrm{H} \times \mathrm{S})}<0.25$ and $\mathrm{dt}=1,32$ if $\mathrm{P}_{\mathrm{L}(\mathrm{HXS})}>0.25$. Pooled error is the estimate of experimental error when $L$ is removed from the model (when $p_{\text {LociHXS) }}>$ 0.25). $\mathrm{p} p<0.05 ;{ }^{\cdots} \mathrm{p}<0.01 ;{ }^{\cdots}{ }^{\mathrm{p}} \mathrm{p}<0.001$

\begin{tabular}{|c|c|c|c|c|}
\hline & Source & MS & $F$ & $\mathrm{p}$ \\
\hline \multicolumn{5}{|c|}{ Settlement on artificial collectors } \\
\hline \multirow[t]{6}{*}{ Sep } & Location $(\mathrm{H} \times \mathrm{S})$ & 1.50 & 1.07 & 0.41 \\
\hline & Habitat & 0.33 & 0.23 & $>0.25$ \\
\hline & Stratum & 3.00 & 2.11 & $0.10<\mathrm{p}<0.25$ \\
\hline & Habitat $\times$ Stratum & 2.08 & 1.47 & $0.10<\mathrm{p}<0.25$ \\
\hline & Residual & 1.40 & & \\
\hline & Pooled error & 1.42 & & \\
\hline \multirow[t]{5}{*}{ Oct } & Location $(\mathrm{H} \times \mathrm{S})$ & 11.52 & 1.93 & 0.086 \\
\hline & Habitat & 133.33 & 11.57 & $0.009^{\cdots}$ \\
\hline & Stratum & 225.33 & 19.56 & $0.002 \cdots$ \\
\hline & Habitat $\times$ Stratum & 24.08 & 2.09 & 0.186 \\
\hline & Residual & 5.97 & & \\
\hline \multicolumn{5}{|c|}{ Settlement on natural substrata } \\
\hline \multirow[t]{5}{*}{ Sep } & Location $(\mathrm{H} \times \mathrm{S})$ & 23.97 & 3.19 & $0.013^{\circ}$ \\
\hline & Habitat & 56.25 & 2.35 & 0.164 \\
\hline & Stratum & 0.03 & 0.001 & 0.974 \\
\hline & Habitat $\times$ Stratum & 90.25 & 3.77 & 0.088 \\
\hline & Residual & 7.53 & & \\
\hline \multirow[t]{6}{*}{ Oct } & Location $(\mathrm{H} \times \mathrm{S})$ & 1.50 & 0.42 & 0.898 \\
\hline & Habitat & 34.03 & 11.12 & $<0.005^{*}$ \\
\hline & Stratum & 0.03 & 0.01 & $>0.25$ \\
\hline & Habitat $\times$ Stratum & 14.69 & 4.80 & $<0.05^{\circ}$ \\
\hline & Residual & 3.58 & & \\
\hline & Pooled error & 3.06 & & \\
\hline \multicolumn{5}{|c|}{ Recruitment on natural substrata } \\
\hline & Location $(\mathrm{H} \times \mathrm{S})$ & 6.17 & 8.87 & $0.000 \cdots$ \\
\hline & Habitat & 7.47 & 1.21 & 0.303 \\
\hline & Stratum & 0.012 & 0.002 & 0.963 \\
\hline & Habitat $\times$ Stratum & 57.67 & 9.35 & $0.016^{\circ}$ \\
\hline & Residual & 0.70 & & \\
\hline
\end{tabular}




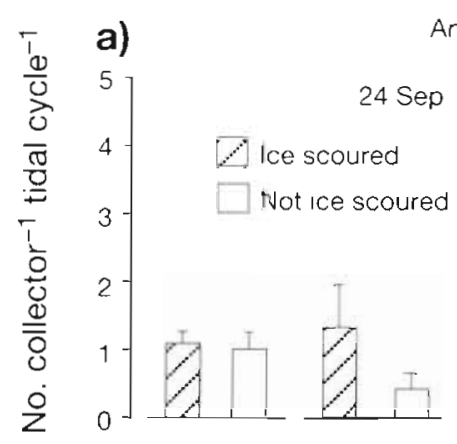

Artificial substratum

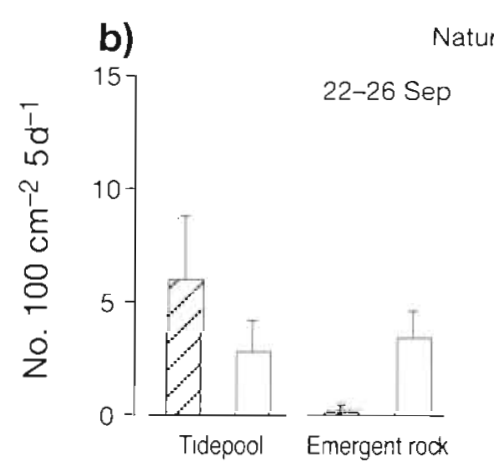

Natural substratum

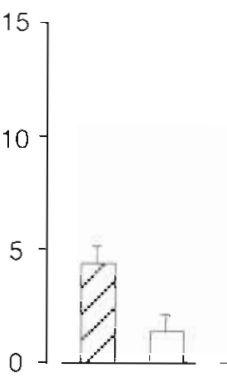

8 Oct
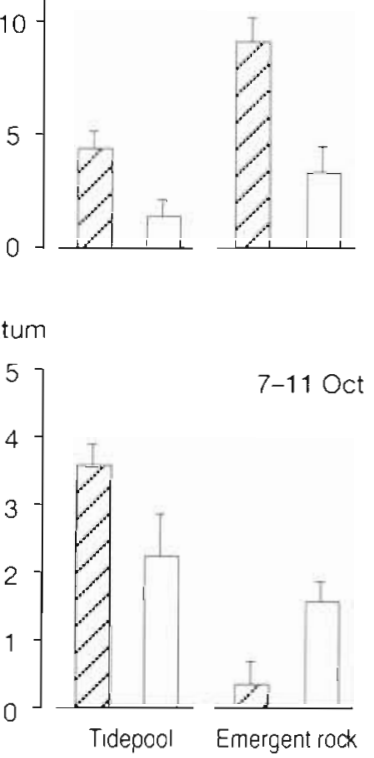

Fig. 4. Mean ( \pm SE) settlement rate of Mytilus in ice-scoured and non-scoured tidepools and emergent rock $(n=3$ locations per Habitat $\times$ Stratum combination): (a) settlement on artificial collectors (no. collector ${ }^{-1}$ tidal cycle ${ }^{-1}$ ) on September 24 and October 8, 1994 (averaged for 4 collectors per location); and (b) settlement on natural substrata [no. $(100 \mathrm{~cm})^{-2}\left(5 \mathrm{~d}^{-1}\right)$ ) on September 22 to 26 and October 7 to 11,1994 (averaged for 3 quadrats per location) were combined $\left(D_{25,21}=0.316 ; \mathrm{p}=\right.$ 0.178 ; Fig 5). In October, $>76 \%$ of mussels in all Habitat $\times$ Stratum combinations ( $n=17$ to 110 ) were $<0.5 \mathrm{~mm}$ SL (Fig. 5). The size distribution of mussels did not differ significantly between scoured and non-scoured tidepools $\left(D_{52.17}=0.182 ; \mathrm{p}=0.758\right)$ or emergent rock $\left(D_{110,40}=0.241_{i} \mathrm{p}=0.069\right)$. There was a statistically significant difference in size distribution $\left(D_{69,150}=\right.$ $0.233_{i} p=0.012$ ) between tidepools and emergent rock when these strata were combined, although the distributions were very similar (Fig. 5).

Regression analysis showed no significant relationship between mussel settlement rate on artificial collectors and the physical characteristics of locations (water flux, tidal height, and flushing time) when tidepools and emergent rock were analyzed separately. However, when locations in both habitats were included in the same regression analysis, there was a significant positive relationship between settlement rate and water flux in October $\left(F_{2,9}=9.653\right.$; $\mathrm{p}=0.006$; water flux $\mathrm{p}=0.002$, tidal height $p=0.074$ ). period of tidal isolation (combining counts for all collectors: $n=12$ and $n=13$, respectively). In October, however, no mussels in non-scoured tidepools and only $8 \%(n=69)$ in scoured tidepools settled during tidal isolation.

Mytilus sampled on the artificial collectors were $<7 \mathrm{~mm}$ SL and the size distribution was highly skewed to the right (Fig. 5). In September, 0.5 to $1 \mathrm{~mm}$ mussels were the most abundant size class (Fig. 5), and size distributions did not differ significantly between scoured and non-scoured tidepools $\left(D_{13,12}=0.378\right.$; $p=0.281$ ), strata wor not compdred for the emergent rock habitat because of the small sample size $(n=5)$ for non-scoured areas. There was no significant difference between tidepools and emergent rock when strata

Fig. 5. Size-frequency distributions of Mytilus on artificial collectors in (a) tidepools and on (b) emergent rock on September 24 and October 8, 1994. Mussels from all collectors $(n=24 ; 4$ collectors per location $\times 6$ locations) from a habitat, including those from both ice-scoured and non-scoured strata, are pooled. In tidepools in September, mussels in the last bar are 5.05 to $7 \mathrm{~mm} \mathrm{SL}$

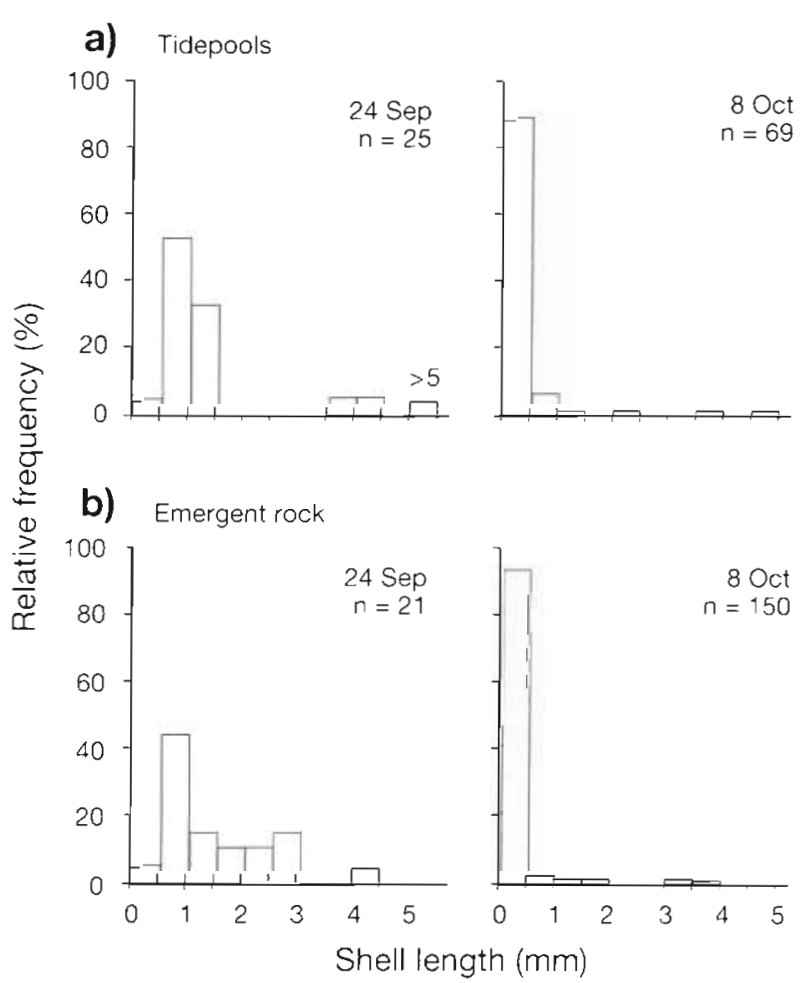




\section{Settlement on natural substrata}

The settlement pattern of Mytilus on natural substrata differed markedly from that on the artificial collectors. In September 1994, settlement rate varied significantly with Location, mainly because of differences among ice-scoured tidepools $\left(F_{2,24}=\right.$ 3.792; $p=0.037 \mathrm{j}_{i}$ differences among locations for other Habitat $\times$ Stratum combinations were non-significant (Table 1 \& Fig. 4b). There were no significant differences in settlement rate with Habitat or Stratum, and no significant interaction between Stratum and Habitat (Table 1 \& Fig. 4b). In October 1994, however, there was no significant variation in settlement rate among locations but there was a significant interaction between Habitat and Stratum (Table 1): settlement rate was significantly higher in ice-scoured tidepools than on the scoured emergent rock (SNK, $p<0.05$ ), but did not differ significantly among the other Habitat $x$ Stratum combinations (Fig. 4b).

In contrast to artificial collectors, the size distributions of Mytilus on the natural substratum were relatively uniform and the mussels were larger (Fig. 6). In October, only $4 \%(n=52)$ of mussels in tidepools and no mussels on emergent rock were $<0.5 \mathrm{~mm}$ SL, the dominant size class on artificial collectors. We only found 1 mussel $>5 \mathrm{~mm}$ SL on artificial collectors; however, mussels sampled on the natural substratum were up to $12 \mathrm{~mm} \mathrm{SL}$, and $31 \%(n=109)$ in September and $20 \%(n=69)$ in October were $>5 \mathrm{~mm}$ SL. The size distributions of mussels did not differ significantly between ice-scoured and non-scoured pools for either sample period (September: $D_{53,24}=0.152 ; \mathrm{p}=0.803$; October: $D_{32,20}=0.262$; $p=0.321$ ); strata were not compared for the emergent rock because of the small sample sizes in scoured areas ( $\mathrm{n}=2$ and 3 in September and October, respectively). The size distributions of mussels in tidepools and on emergent rock were similar in September $\left(D_{77,32}=\right.$ $0.241 ; \mathrm{p}=0.131$ ), but differed significantly in October $\left(D_{52.17}=0.519 ; \mathrm{p}=0.002\right)$ when mussels $<1 \mathrm{~mm}$ SL were absent on emergent rock but comprised the most abundant size class in tidepools (Fig. 6).

To examine the relationship between mussel settlement rate on the natural substratum and the physical and biological characteristics of locations, we used 3 PCA factors for tidepools (94.9\% of variance) and emergent rock $(92.8 \%$ of variance) and 4 PCA factors for the combined habitats ( $87.7 \%$ of variance) (Table 2 ). There was no consistent relationship between settlement rate and PCA factor scores between sample periods and mussel size classes (Tables 2 \& 3). In September, mussels $<2 \mathrm{~mm}$ SL on emergent rock varied significantly with a factor (Factor 1) with high positive

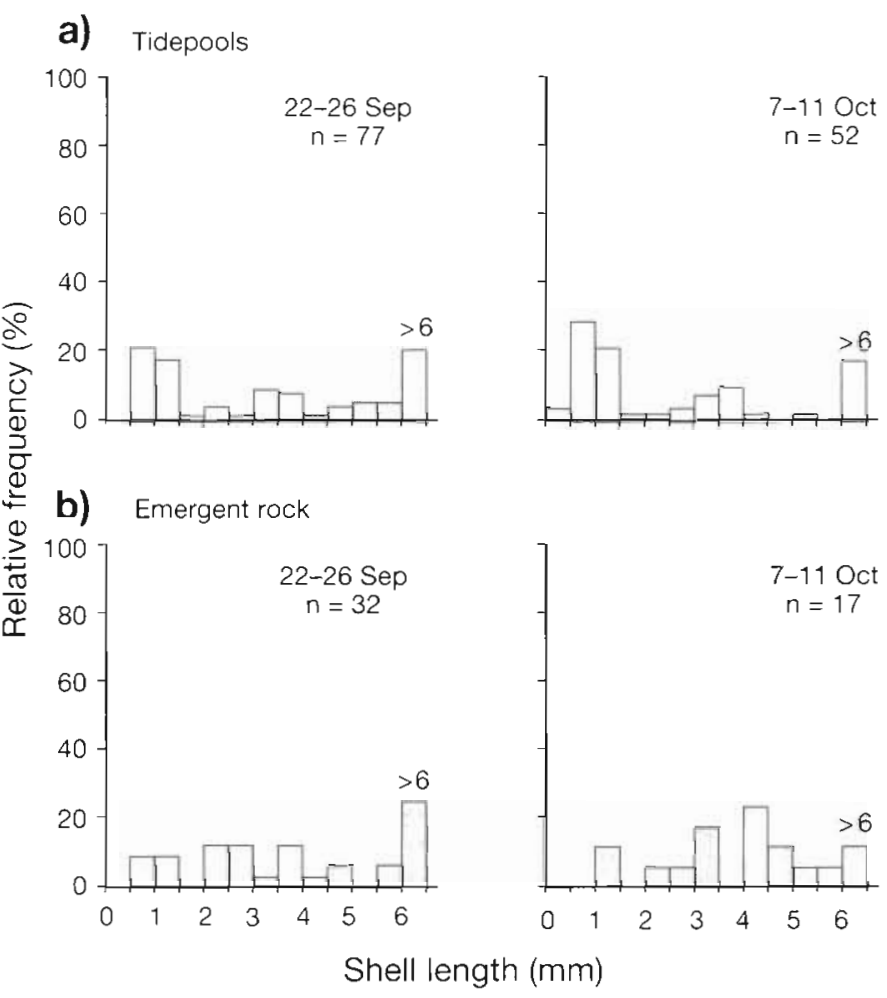

Fig. 6. Size frequency distributions of Mytilus on natural substrata in (a) tidepools and on (b) emergent rock on September 22 to 26 and October 7 to 11,1994 . Mussels from all quadrats $(\mathrm{n}=18 ; 3$ quadrats per location $\times 6$ locations) from a habitat, including those from both ice-scoured and non-scoured strata, are pooled. Mussels in the last bar are 6.05 to $12 \mathrm{~mm} \mathrm{SL}$

component loadings for water flux and crustose macroalgae. In October, mussels $<2 \mathrm{~mm}$ SL in tidepools varied significantly with a factor (Factor 1) with high negative component loadings for flushing time, bare space, tidal height, and water flux index. When both habitats were combined in the same analysis, mussels $>2 \mathrm{~mm}$ SL in September varied significantly with one factor (Factor 3) with a positive loading for coarsely branched algae and a negative loading for bare space, and another (Factor 4 ) with a positive loading for thick leathery macroalgae and a negative loading for coarsely branched macroalgae. In contrast, mussels $<2 \mathrm{~mm}$ SL in October varied significantly with one factor (Factor 1) with positive loadings for crustose macroalgae, water flux, and jointed calcareous and filamentous algae, and another (Factor 2) with a positive loading for tidal height.

\section{Recruitment}

On natural substrata, the pattern of recruitment of Mytilus after 5 mo reflected the pattern of settlement (Fig. 7). Recruitment rate varied significantly with 


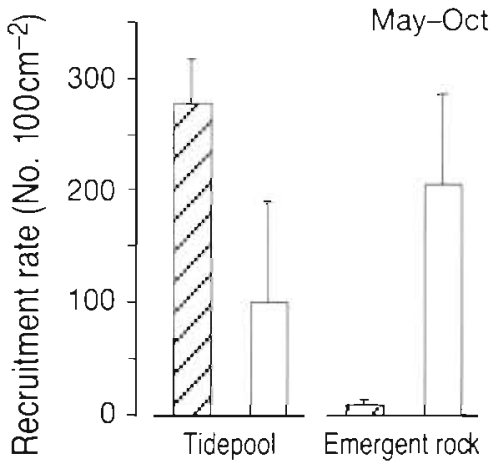

Ice scoured $\square$ Not ice scoured

Fig. 7. Mean $( \pm \mathrm{SE})$ abundance of Mytilus recruits on natural substrata [no. $(100 \mathrm{~cm})^{-2}$ ] in ice-scoured and non-scoured tidepools and emergent rock $(n=3$ locations per Habitat $x$ Stratum combination) sampled in October 1994 from quadrats cleared of mussels in May 1994 (averaged for 3 quadrats per location)

Table 2. Results of PCA of physical and biological characteristics of locations at Cranberry Cove, Nova Scotia. Only factors with eigenvalues $>1$ and components with loadings $>0.5$ or $<-0.5$ are shown. Components are listed in order of descending loadings. $\mathrm{n}=6$ locations for tidepools or emergent rock, and $\mathrm{n}=12$ when the habitats are pooled. Functional form groups of macroalgae: FIL = filamentous; $\mathrm{CB}=$ coarsely branched; $\mathrm{JC}=$ jointed calcareous $\mathrm{TL}=$ thick leathery; $\mathrm{CR}=$ crustose $; \mathrm{BA}=$ barnacles; $\mathrm{BE}=$ bare substratum. Physical characteristics:

TID = tidal height $;$ WFI = water flux index $;$ FLU = flushing time

\begin{tabular}{|c|c|c|c|}
\hline Habitat & Eigenvalue & $\begin{array}{l}\% \text { Variance } \\
\text { explained }\end{array}$ & Components \\
\hline \multicolumn{4}{|l|}{ Tidepool } \\
\hline Factor 1 & 3.801 & 47.51 & -FLU, -BE, -TID, -WFI, FIL, JC, CB \\
\hline 2 & 2.724 & 34.05 & $-\mathrm{CB}, \mathrm{FIL}, \mathrm{JC}, \mathrm{CR}, \mathrm{WFI}$ \\
\hline 3 & 1.068 & 13.35 & $-C R$ \\
\hline \multicolumn{4}{|c|}{ Emergent rock } \\
\hline Factor 1 & 2.945 & 42.07 & WFI, CR, $-B E, T I D$ \\
\hline 2 & 2.202 & 31.46 & $-T L, B A, B E$ \\
\hline 3 & 1.347 & 19.24 & $C R,-T I D$ \\
\hline \multicolumn{4}{|c|}{ Combined habitats } \\
\hline Factor 1 & 3.571 & 39.68 & CR, WFI, JC, FIL, -TL, -BA, -BE \\
\hline 2 & 1.839 & 20.43 & TID,$-F I L$ \\
\hline 3 & 1.444 & 16.05 & $\mathrm{CB},-\mathrm{BE}$ \\
\hline 4 & 1.039 & 11.54 & $T L,-C B$ \\
\hline
\end{tabular}

Location: there was significant variation among scoured tidepools $\left(F_{2,24}=30.336 ; \mathrm{p}<0.001\right)$ but not among locations in the other Habitat $\times$ Stratum combinations. There was a significant interaction between Habitat and Stratum (Table 1). Mussel recruits were significantly more abundant in ice-scoured tidepools than on scoured emergent rock (SNK, p < 0.05); there was no significant variation among the other Habitat $x$ Stratum combinations

\section{DISCUSSION}

Settlement rate of Mytilus on artificial collectors was directly related to water flux, and was highest on the ice-scoured emergent rock and lowest in non-scoured tidepools. This pattern probably reflects an increase in larval supply with increased water flux. Bushek (1988) found a similar positive relationship between barnacle settlement rate and water motion which he attributed to both larval supply and selective settlement. In our study, settlement on collectors placed on ice-scoured emergent rock may also have been enhanced by the apparent unsuitability of the surrounding substratum (where settlement rate was low). A similar effect has been reported by Pineda (1994), who found that barnacles settled at higher densities at sites surrounded by unsuitable sandy substratum. Horizontal variability in the availability of settlers did not contribute to the pattern, since the abundance of competent larvae in the surrounding sea water did not vary significantly over the $1 \mathrm{~km}$ of shore spanning our sampling locations.

Artificial collectors have been widely used in studies monitoring the abundance of mytilid larvae (King et al. 1990 and references therein, CáceresMartínez et al. 1994, Molares \& Fuentes

Table 3. Significant forwards stepwise multiple regressions relating abundance of Mytilus $<2$ and $>2$ mm SL on natural substrata in September and October 1994 to factor scores obtained by PCA on physical and biological charactenstics of locations at Cranberry Cove, Nova Scotia. F1 to F4 = PCA factors from Table 2. Independent variables with significant partial F-values are shown in bold

\begin{tabular}{|c|c|c|c|c|c|c|}
\hline Habitat & Month & Size (mm SL) & Model & $\mathrm{R}^{2}$ & $F$ & $\mathrm{p}$ \\
\hline Tidepool & Oct & $<2$ & $3.093+2.194(\mathbf{F} 1)$ & 0.925 & 49.25 & 0.002 \\
\hline Emergent rock & Sep & $<2$ & $0.333+0.248(\mathrm{~F} 1)$ & 0.692 & 8.98 & 0.040 \\
\hline Combined habitats & $\begin{array}{l}\text { Sep } \\
\text { Oct }\end{array}$ & $\begin{array}{l}>2 \\
<2\end{array}$ & $\begin{array}{l}1.972+1.141(\mathbf{F} 3)-1.013(\mathbf{F} 4) \\
0.861+0.634(\mathbf{F} 1)-0.485(\mathbf{F} 2)-0.287(\mathrm{~F} 4)\end{array}$ & $\begin{array}{l}0.672 \\
0.800\end{array}$ & $\begin{array}{r}9.21 \\
10.68\end{array}$ & $\begin{array}{l}0.004 \\
0.007\end{array}$ \\
\hline
\end{tabular}


1995), but such studies cannot fully explain settlement patterns between habitats or sites because they do not account for the spatial variability of the natural substratum. In our study, the settlement patterns of Mytilus differed markedly between artificial collectors and natural substrata. In contrast to the collectors, settlement on natural substrata was greatest in icescoured tidepools and minimal on scoured emergent rock. This difference in settlement patterns between artificial and natural substrata is probably related to variation in the macrobenthic assemblage between habitats and strata. In this study, ice-scoured emergent rock was devoid of filamentous or coarsely branched macroalgae, which are known to promote settlement of Mytilus (reviewed by Seed 1976, Seed \& Suchanek 1992), and had less crustose macroalgae than the other habitat and stratum combinations. Multiple regression did not reveal a consistent relationship between settlement rate on natural substrata and any particular macroalgal group, but there were some associations between either small or large settlers and a suite of biological and physical factors.

In October, mussels $<1 \mathrm{~mm}$ SL on natural substrata were common in tidepools but absent on emergent rock. Filamentous and jointed calcareous algae, which were found only in tidepools, may be more suitable settlement sites for mussel larvae and early postlarvae than thick leathery macroalgae, the predominant erect form on emergent rock. Also, mussels < $1 \mathrm{~mm} \mathrm{SL}$ settle in tidepools during the period of tidal isolation, although only a small proportion of mussels settled on our artificial collectors during tidal isolation in October.

The relationship between the settlement rate of Mytilus and macroalgal substrata may depend upon both active substratum choice and passive hydrodynamic processes, and the processes and cues involved probably vary with spatial scale. Active substratum choice by Mytilus was suggested by Bourget et al. (1994) who examined the establishment of an epibenthic community on panels with various combinations of scales of substratum heterogeneity $(1,10$, and $100 \mathrm{~mm}$ wide grooves). Bivalve settlers, including $M$. edulis, were aggregated at particular scales of heterogeneity, suggesting they are active settlers; in contrast, bryozoans were uniformly distributed, suggesting they are passive settlers. However, Harvey et al. (1995) found that passive settlement processes were sufficient to explain settlement patterns at decimetre scales (on plastic filamentous substrata) of several species of bivalves, including $M$. edulis. CáceresMartínez et al. (1994) have suggested that the association of postlarvae of $M$. galloprovincialis with filamentous substrata results from passive ensnarement of these substrata by byssus threads secreted by the postlarvae, rather than active selection.
Most Mytilus settlers in our study (with the exception of those on artificial collectors in October) were $>0.5 \mathrm{~mm}$ SL and were probably not settling for the first time. Secondary settlement of postlarvae of $M$. edulis on adult mussel beds, after a second pelagic phase following detachment from initial settlement sites on filamentous algae, was first described by Bayne (1964). Subsequent studies have shown that movement of postlarval mussels, either by drifting in the water column on mucous threads (Sigurdsson et al. 1976, De Blok \& Tan-Maas 1977, Lane et al. 1985) or by crawling along the substratum (Harger 1968, Seed \& Suchanek 1992, Cáceres-Martínez et al. 1994), may be important in determining distributional patterns of recruits. However, settlement behaviour of Mytilus appears to vary considerably among populations: mussels may settle directly onto adult beds (reviewed by Seed \& Suchanek 1992), or they may repeatedly settle on various substrata and disperse until they die or reach a suitable settlement site (Cáceres-Martínez et al. 1994).

In our study, the size of mussel settlers was much smaller on artificial collectors than on natural substrata. We found only 1 mussel $>5 \mathrm{~mm}$ SL on a collector, which is consistent with the small sizes reported in previous studies using artificial collectors (e.g. Bayne 1964, Bohle 1971, King et al. 1990). In contrast, 20 to $30 \%$ of settlers on natural substrata were $>5 \mathrm{~mm} \mathrm{SL}$, suggesting that postlarval mussels in this area move repeatedly. Paine (1974) also observed that relatively large (>3 cm SL) $M$. californianus colonized cleared plots in the intertidal zone in Washington, USA. The filamentous substrata generally used in artificial collectors may be more suitable for smaller, early postlarvae than for the larger, later stages (Seed 1969). Also, mussels $>5 \mathrm{~mm}$ SL may disperse by crawling but are probably too heavy to drift on byssal. threads, reducing the likelihood of sampling them in studies which use collectors suspended in the water column.

The pattern of recruitment of Mytilus that we observed on natural substrata after 5 mo reflected the pattern of settlement after $5 \mathrm{~d}$, suggesting that spatial variations in settlement are important in determining the abundance and distribution of mussels in this population. However, the recruitment that we measured between May and October may largely reflect a fall peak in primary settlement, as was evident from the increase in settlement rate between September and October (see also Pedersen 1991). Recruitment patterns of a number of groups of benthic invertebrates have been related to their settlement patterns, particularly in cases where settlement rate is low (reviewed by Rodríguez et al. 1993). However, little is known about recruit-settler relationships in mussels.

The settlement and recruitment patterns of Mytilus that we observed on natural substrata correspond to 
the patterns of distribution and abundance of mussels on ice-scoured but not non-scoured regions of the shore. On non-scoured substrata, mussels occur in smaller patches in tidepools than on the emergent rock. The rates of settlement and recruitment (after 5 mo) that we measured did not differ significantly between non-scoured tidepools and emergent rock, suggesting that this pattern is generated by later postsettlement processes. In contrast, mussels are rare on ice-scoured emergent rock, which probably reflects low settlement rates, as indicated by our low counts of both settlers and recruits on the natural substratum in these areas. Settlement rate is clearly not limited by larval supply to these areas, since the highest settlement rates were recorded on artificial collectors on icescoured emergent rock. Our study underscores the importance of measuring settlement on both a standardized artificial substrate and the natural substratum to compare the relative roles of larval supply and substratum type in determining patterns of settlement in a spatially variable environment.

Acknowledgements. We thank Shelley Lang, Michael Gedamke, Kristina Sander, Anna Metaxas and Susanne Meidel for assistance in the field, and Paul Rawson. for genetic analysis of the mussels. We are also grateful to Chris Pearce, Tony Chapman, and Anna Metaxas for their comments on earlier drafts of this manuscript. Bruce Bradshaw at the Marine Environmental Data Services Branch of Fisheries and Oceans in Ottawa, Canada provided data on signiticant wave heights. H.L.H. was supported by a Natural Science and Engineering Research Council (NSERC) Postgraduate Award and an lzaak Walton Killam Memorial Scholarship from Dulhousie. University and the research was supported by an 'VSERC Research Grant to R.E.S.

\section{LITERATURE CITED}

Bayne BL (1964) Pnmary and secondary settlement in Mytilus edulis L. (Mollusca). J Anim Ecol 33:513-523

Bayne BL (1965) Growth and the delay of metamorphosis of the larvae of Mytilus edulis (L.). Ophelia 2:1-47

Bohle B (1971) Settlement of mussel larvae Mytilus edulis on suspended collectors in Norwegian waters. In: Crisp DJ (ed) Proceedings of the Fourth European Marine Biology Symposium. Cambridge University Press, London, p $63-69$

Bourget E, DeGuise J, Daigle G (1994) Scales of substratum heterogeneity, structural complexity, and the early estat)lishment of a marine epibenthic community. J Exp Mar Biol Ecol 181:31-51

Bushek D (1988) Settlement as a major determinant of intertidal oyster and barnacle distributions along a horizontal gradient. J Exp Mar Biol Ecol 122:1-18

Butman CA (1987) Larval settlement of soft sediment invertebrates: the spatial scales of pattern explained by active habitat selection and the emerging role of hydrodynamical processes. Oceanogr Mar Biol Arn Rev 25:113-165

Caceres-Martínez J, Robledo JAF, Figueras A (1994) Settlement and post-larvae behaviour of Mytilus galloprovincialis: field and laboratory experiments. Mar Ecol Prog Ser 112:107-117
De Blok JW, Tan-Maas M (1977) Function of byssus threads in young postlarval Mytilus. Nature $267: 558$

Eckman JE (1983) Hydrodynamic processes affecting benthic recruitment. Limnol Oceanogr 28:241-257

Eckman JE (1987) The role of hydrodynamics in recruitment, growth, and survival of Argopecten irradians (L.) and Anomia simplex (D'Orbigny) within eelgrass meadows. J Exp Mar Biol Ecol 106:165- 191

Eggleston DB, Armstrong DA (1995) Pre- and post-settlement determinants of estuarine Dungeness crab recruitment. Ecol Monogr 65:193-216

Eyster LS, Pechenik JA (1987) Attachment of Mytilus edulis L. larvae on algal and byssal filaments is enhanced by water agitation. J Exp Mar Biol Ecol 114:99-110

Harger JRE (1968) The role of behavioral traits in influencing the distribution of two species of sea mussel, Mytilus edulis and Mytilus californianus. Veliger 11:45-49

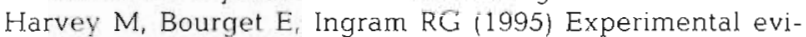
dence of passive accumulation of marine bivalve larvae on filamentous epibenthic structures. Limnol Oceanogr 40: $94-104$

Havenhand JN, Svane I (1991) Roles of hydrodynamics and larval behaviour in determining spatial aggregation in the tunicate Ciona intestinalis. Mar Ecol Prog Ser 68:271-276

Hunt HL, Scheibling RE (1995) Structure and dynamics of mussel patches in tidepools on a rocky shore in Nova Scotia, Canada. Mar Ecol Prog Ser 124:105-115

Keough MJ, Downes BJ (1982) Recruitment of marine invertebrates: the role of active larval choices and early mortality. Oecologia 54:348-352

King PA, McGrath D, Britton W (1990) The use of artificial substrates in monitoring mussel (Mytilus edulis L.) settlement on an exposed rocky shore in the west of Ireland. J Mar Biol Ass UK 70:371-380

Kleinbaum DG, Kupper LL, Muller KE (1988) Applied regression analysis and other multivariable methods. PWSKENT, Boston

Lane DJW, Beaumont AR, Hunter JR (1985) Byssus drifting and the drifting threads of the young post-larval mussel Mytilus edulis. Mar Biol 84:301-308

Littler MM (1980) Morphological form and photosynthetic performances of marine macroalgae: tests of a functional/ form hypothesis. Botanica Mar 22:161-165

Littler MM, Littler DS (1984) Relationships between macroalgal functional form groups and substrata stability in a subtropical rocky-intertidal system. J Exp Mar Biol Ecol $74: 13-34$

Mallet AL, Carver CE (1995) Comparative growth and survival patterns of Mytilus trossulus and Mytilus edults in Atlantic Canada. Can J Fish Aquat Sci 52:1873-1880

Martel A, Mathieu AF, Findlay CS, Nepszy SJ, Leach JH (1994) Daily settlement rates of the zebra mussel. Dreissena polymorpha, on an artificial substrate correlate with veliger abundance. Can J Fish Aquat Sci 51:856-861

McCook LJ, Chapman ARO (1991) Community succession following massive ice-scour on an exposed rocky shore effects of Fucus canopy algae and of mussels during late succession. J Exp Mar Biol Ecol 154:137-169

Menge BA (1978) Predation intensity in a rocky intertidal community. Effect of an algal canopy, wave action and desiccation on predator feeding rates. Oecologia 34:17-35

Menge BA, Beriow EL, Blanchette CA, Navareite SA, Yamada SB (1994) The keystone species concept: variation in interaction strength in a rocky intertidal habitat. Ecol Monogr 64:249-286

Metaxas A. Hunt HL, Scheibling RE (1994) Spatial and temporal variability of macrobenthic communities in tidepools 
on a rocky shore in Nova Scotia, Canada. Mar Ecol Prog Ser 105:89-103

Metaxas A, Scheibling RE (1993) Community structure and organization of tidepools. Mar Ecol Prog Ser 98:187-198

Minchinton TE, Scheibling RE, Hunt HL (in press) Recovery of an intertidal assemblage following massive ice scour in Nova Scotia, Canada. Botanica Mar

Molares J, Fuentes J (1995) Recruitment of the mussel Mytilus galloprovincialis on collectors situated on the intertidal zone in the Ria de Arousa (NW Spain). Aquaculture 138: $131-137$

Paine RT (1974) Intertidal community structure: experimental studies on the relationship between a dominant competitor and its principal predator. Oecologia 15:93-120

Pawlik JR (1992) Chemical ecology of the settlement of benthic marine invertebrates. Oceanogr Mar Biol Ann Rev 30:273-335

Pearce CM, Bourget E (1996) Settlement of larvae of the giant scallop, Placopecten magellanicus (Gmelin), on various artificial and natural substrata under hatchery-type conditions. Aquaculture 141:201-222

Pedersen EM (1991) Population genetics of Mytilus from a developing intertidal community in Nova Scotia, Canada. MSc thesis, Dalhousie University, Halifax

Pettrsen JH (1984) Larval settlement behavior in competing species: Mytilus californianus Conrad and $M$. edulis $L$. J Exp Mar Biol Ecol 82:147-159

Petraitis PS (1991) Recruitment of the mussel Mytilus edulis L. on sheltered and exposed shores in Mane, USA. J Exp Mar Biol Ecol 147:65-80

Pineda J (1994) Spatial and temporal patterns in barnacle settlement rate along a southern California rocky shore. Mar Ecol Prog Ser 107:125-138

Rawson PD, Hilbish TJ (1995a) Evolutionary relationships

This article was presented by R. N. Hughes (Senior Editorial Advisor), Bangor, UK among the male and female mitochondrial DNA lineages in the Mytilus edulis species complex. Mol Biol Evol 12: $893-901$

Rawson PD. Hilbish TJ (1995b) Distribution of male and female mtDNA lineages in populations of blue mussels, Mythlus trossulus and $M$. galloprovincialis, along the Paclic coast of North America. Mar Biol 124:245-250

Rawson PD, Joyner KL, Meetze K, Hılbish TJ (in press) Evıdence for intragenuc recombination withm a novel genetic marker that distınguishes mussels in the Mytilus edulis species complex. Heredity, Lond

Rodríguez SR, Ojeda FP, Inestrosa NC (1993) Settlement of benthic marine invertebrates. Mar Ecol Prog Ser 97 $193-207$

Seed R (1969) The ecology of Mytnlus edulis L. (Lamellibranchiata) on exposed rocky shores 1 . Breeding and settlement. Oecologia 3:277-316

Seed R (1976) Ecology. In: BL Bayne (ed) Marine mussels: their ecology and physiology. Cambridge University Press, London, p 13-65

Seed R, Suchanek TH (1992) Population and community ecology of Mytilus. In: Gosling E (ed) The mussel Mytilus: ecology, physiology, genetics, and culture. Elsevier, New York, p 87-169

Seigel S, Castellan NJ Jr (1988) Nonparametric statistics for the behavioral sciences. McGraw-Hill, New York

Sigurdsson JB, Titman CW, Davies PA (1976) The dispersal of young post-larval bivalve molluscs by byssus threads. Nature 262:386-387

Winer BJ (1971) Statistical principles in experimental design McGraw-Hill, New York

Yund PO, Gamnes SD, Bertness MD (1991) Cylindrical tube traps for larval sampling. Limnol Oceanogr 36: $1167-1177$

Manuscript first received: April 22, 1996

Revised version accepted: August 9, 1996 